DOI: $10.1515 /$ ausfm-2015-0026

\title{
Rhizomatic Narrative and Intermediality in Treme
}

\author{
Adrián Bene \\ University of Pécs (Hungary) \\ E-mail: beneadrian@gmail.com
}

\begin{abstract}
In this paper, I study the narrative structure and the layers of meaning in the Treme (2010-2013), using the concept of rhizome introduced in A Thousand Plateaus by Deleuze and Guattari (1987) and the Hannerzian "root metaphor" of creole culture. As for New Orleans in the Treme, music makes the narrative structure not just multilinear but rhizomatic. Moreover, spontaneity and hybridity highlight dialogicity and poliphony as well as a strong ironic and subversive capacity concerning music and creole culture. On a narratological level, analysing the critical representation of social problems after the destruction of Hurricane Kathrina raises the problems of focalization and narratorial distance.
\end{abstract}

Keywords: rhizomatic narrative, hybridity, intermediality, creolization, lived experience.

The present paper focuses on the special narrative structure of Treme (20102013), the peculiarity of which is in great part due to its musical aspects. I have to note that my remarks concern principally the first season of Treme and in a less degree the second, third and fourth season, since these are much more similar to the first season of David Simon's The Wire (2002-2008), reflecting on the phenomena of institutional corruption and dysfunction. Instead of these similarities, I shall point to such narratological features as hybridity, diversity, otherness, rhizomatic narrative and intermediality.

The concept of rhizome articulated in A Thousand Plateaus of Deleuze and Guattari (1987) has recently proved to be very fruitful in narratology. Actually, rhizomatic narrative is not just a special case of non-linear narrative structure which has no beginning or end, consisting of a series of links where every link creates multiple other links, always growing and moving. David Simon's and Eric Overmeyer's "fictional cine-journalism" in The Wire and in Treme can be considered "aiming for some giant truth" (Knight 2011), while Treme does 
not just tell us something about the USA, but shows us a local culture from an ethnographic view-point. As a television drama series that makes us hear the sounds of New Orleans through various musical scenes, it is something like the book of Deleuze and Guattari itself: "body without organs, which is continually dismantling the organism, causing signifying particles or pure intensities to pass or circulate, and attributing to itself subjects that it leaves with nothing more than a name as the trace of an intensity" (Deleuze and Guattari 1987, 4). The city in the state of disintegration and the quest for its identity share the very feature of "assemblage". This "machine" of "multiplicities, lines, strata and segmentarities, lines of flight and intensities" (Deleuze and Guattari 1987, 4) functions in Treme, that is why the ideology should be considered of secondary importance here. The openness and unpredictability of the plot ensue from the principles of connection and heterogeneity (Deleuze and Guattari 1987, 7).

Thus, the music does not just illustrate the storylines, it becomes the main theme of the show being made narrative by introducing characters and plotlines. The improvisative music and the well-known musicians here serve not just to provide a kind of couleur local, but present an effect of spontaneity and contingency. As Nietzsche put it in The Birth of Tragedy, music can "transport people to drunken enthusiasm" (Nietzsche 1923, 52) causing "the orgiastic feeling of freedom" (Nietzsche 1923, 160), an "orgiastic self-annihilation" (Nietzsche 1923, 163) uplifting us from conscious, conceptual thinking. The Dyonysian artist "become altogether one with the Primordial Unity, its pain and contradiction, and he produces the copy of this Primordial Unity as music" (Nietzsche 1923, 45). The ecstatic feature later lost its tragic dimension in the Nietzschean concept of Dyonysiac music and he shifts the focus on the rhythm encompassing the whole body in the dance, while "the whole affective system is excited and enhanced" (Nietzsche 2013, 45). The Attempt at Self-Criticism, written in 1886, before the second edition of The Birth of Tragedy emphasizes the subversive character of this Dyonysiac music, quoting Zarathustra: "raise up your legs, you fine dancers, and better yet, stand on your heads!” (Nietzsche 1923, 15.)

Moreover, music transforms the narrative structure of the series from a multilinear story to a rhizomatic narrative in an intermedial way. In this rhizomatic structure, music represents New Orleans as a connecting space for every character and their life-stories. In this subversive manner, traditional narrative structure in Treme gives place to non-narrative music as symbol of New Orleans and becomes its particular narrative vehicle that "ceaselessly establishes connections between semiotic chains" (Deleuze and Guattari 1987, 7). 


\section{The Creole City}

In a broader context, Treme has its roots in those films that portray the everyday life of a city, as Walter Ruttmann's Berlin: Symphony of a Great City (1927) or Dziga Vertov's Man with a Movie Camera (1929). Ruttmann’s work is an important piece of non-narrative experimental cinema using the documentary filmmaking technique. The montage technique of these early city movies is evoked only in the intro of Treme, but the juxtaposition of narrative sequences is typical of the whole series. This narrative structure can be described using Allan Cameron's concept of database or modular narrative, as well as the concept of rhizome. Since David Simon's intention was to make an argument for the American city that serves as a melting pot (cf. Beiser 2011), I prefer the latter concept, focusing on interconnections, organicity and contingency. The authorial intention also sets the topics of city and creolization together. As for the rhizomatic feature, this is obvious, and shows that "there is no language in itself, nor are there any linguistic universals, only a throng of dialects, patois, slangs” (Deleuze and Guattari 1987, 7).

Even the word "creole" has its roots in Louisiana; it originally referred to old French families and their local dialect, cuisine and music. For Robin Cohen, creolization has a subversive potential because of its "diversity, complexity, hybridity," and traditional jazz is the par excellence creole music (Cohen 2007, 7). "Creative, transformative, and sometimes improvisatory dimensions of creolization" (Spitzer 2011) are interconnected with the rhizomatic narrative structure of Treme based on the central role of local music. Intermediality tends to represent the cross-fertilization in a special, rhizomatic way, which makes the multilinear narrative less linear. This minimal narrative linearity shows up in the slow pacing of the film, disliked by some. This characteristic stems from the special genre of reportage/portrait/fresco of the series in which "New Orleans speaks for itself" (S2E9). It implies also "the overwhelming focus on character over plot” (Sepinwall 2010). Moreover, as Paul Owen emphasizes, "it ignores the structure of the medium Simon works in, and the episodic way most people still watch television programmes" (cf. Owen 2011a). Moreover, the commitment of the "implied author"-like narrative instance is obvious, it takes a stance against the "order," i.e. the federal politics that is not based on solidarity. This social and cultural protest implies some structural characteristics in the narrative that emphasize the otherness: the central role of music as a non-narrative, nonrational experience, and the rhizomatic plotline, presenting the variegation of New Orleans, a place where the local icon, Kermit Ruffins has not ever heard 
about Elvis Costello. Nevertheless, both of these narrative features constitute a tension, since "'the' truth and 'the' reality does not exist within rhizomatic thinking” (Sermijn, Devlieger and Loots 2008, 6). It seems that rhizome functions here as a narrative and ideological device subject to a far-from-post-structuralist authorial intention.

Thus, rhizome means here a narrative structure in which the multiplied linear storylines (in the first season: the search for Ladonna's brother, the struggle of Creighton Bernette, or that one of Jeanette's and Albert's efforts to save the traditions of Mardi Gras Indians, Antoine Batiste's way back to his sons, the relationship of Sonny and Annie, both being also musicians) span the episodes in a way that makes the plotline of a single episode nonlinear, even chaotic. There are episodes consisting of gigs for the most part (e.g. S1E2, S1E4), pushing (linear) narrative further into the background. (In the second and third seasons, the role of music is much more traditional in terms of narrative, that is, it illustrates or slows the plot or provides the shift between the storylines.) The narrative fiction's fictiveness is loosened by the transgressive fact that some characters are played by real-life musicians in a cameo, like Annie by Lucia Micarelli, and many real-life musicians appear in Treme playing themselves. Thus, the artificial linearity of narrative is somehow neglected by life's vagueness. Paul Owen is right: "it is clear that Simon and his co-writers and directors were intent on creating something deliberately, wilfully, defiantly undramatic, in an attempt to mirror New Orleanians' slow, narrative-free struggle to rebuild their lives" (Owen 2011c).

Nevertheless, the thesis of non-narrativity must be defined more precisely. There is plot and progression, as Simon itself points out in another interview (Sepinwall 2010), but it is a matter of fact that it does not check up with the standard tropes of a standard television drama, the narrativity of which is based on typical dramatic moments. Simon rules out these clichés because he does not want to tell a story which is pure fiction, that is, a lie. This committed realism is represented by Creighton's dead-end trying to write a novel that is too "academic" for him (S1E5) (which is a transcendental mise en abyme ${ }^{1}$ in Dällenbach's terminology). He feels it superfluous compared with becoming the vulgar, popular Youtube voice of his city. "There are times when raise is the rational response" - as the famous American writer Roy Blount appearing in $a$ cameo (in S1E5) tells about him.

1 The French narratologist states that the transcendenatal mise en abyme does not just duplicate an element of the story, but through this analogy, the author interprets and evaluates certain common features of the story and his own reality (Dällenbach 1977, 120). 
Subversive, critical power of creolization is rooted in the outsider or inbetween position that "allows the periphery to talk back" (cf. Hannerz 1992, 265). The protestation against federal government politics after Katrina is obvious. It raises the problem of aesthetic distance in a fiction even in the case of a television drama. Using mouthpieces, formulating social and political criticism, aiming a "big truth" is unsettingly "unsubtle" for some (e.g. Knight 2011, Owen 2011b).

In the ninth episode of the second season, Davis said: "You know what Katrina made clear? I'm no longer from the United States of America." The intermedial effects and the rhizomatic narrative structure are made for representing this special status of The Big Easy as a Dyonysiac city (in the Nietzschean sense), where music, weed, cuisine belong to everyday life. Thus, the Mardi Gras carnival can be interpreted as a symbol of the city's subversive otherness (from a Protestant American perspective) and in the Bakhtinian sense as a symbol of plurality, polyphony and dialogue. This heteroglossia and polyphony is the very characteristic of local culture, represented by various musical scenes, implying the idea of rebel versus Order. For instance, in the sixth episode of the second season, Davis holds Public Enemy and The Clash up as models for the young rapper, Lil Calliope. Moreover, Davis's hybrid hip-hop metal brass funk project as "musical insurrection" (S2E9) can be interpreted as a mise en abyme-like discursive figure of ironic self-reflexivity. The living tradition of African American music represents "the greatest American cultural contribution" for David Simon (Beiser 2011); this is why he inverts the traditional roles of story and music in Treme, focusing on the latter.

As a place, New Orleans represents a special deterritorialized space, a virus, a Pink Panther (in the Deleuzian sense) (Deleuze and Guattari 1987, 10-11) through music, that "has always sent out lines of flight, like so many 'transformational multiplicities,' even overturning the very codes that structure or arborify it; that is why musical form, right down to its ruptures and proliferations is comparable to a weed, a rhizome." (Deleuze and Guattari 1987, 11-12.) It is the "smooth space" of Go where "the movement is not from one point to another, but becomes perpetual, without aim or destination, without departure or arrival” (Deleuze and Guattari 1987, 353).

Moreover, there is an at-once ethnographic and hermeneutic implication that must be mentioned here. Because of the density of local references, an intensive activity of the viewer is needed to understand the show. A stranger has to follow the Times-Picayune or search the Treme Wiki, the HBO Treme homepage just like an ethnographer when mapping out cultural meanings. The mission is always 
impossible, even for a New Orleanian who is not Indian but shares the more traditional layer of New Orleanian identity. (See the bar scene of Ladonna and big chief Albert Lambreaux in the third season: "you ain't indian" but "there's always hope" S3E6). As a self-ironic mise en abyme, it alludes to the ethnographic perspective shared by the authors and the audience, as well.

\section{Identity, Difference and Irony}

In the ninth episode of the first season, Creighton has to explain to his students that "creole in the old sense of creole" does not mean coloured, because they do not know that when capitalized, "Creole" refers to the self-identification of people inhabiting $19^{\text {th }}$-century New Orleans, descended from early (primarily francophone and Catholic) settlers. Thus, the word means to be different from the American neighbours (Dawdy and Matthews 2010, 273). Since "everyone in New Orleans eventually becomes Creole," Creole consciousness became less specific in terms of ethnic and social roots: a new identity was forged (Dawdy and Matthews 2010, 282). The difference between the New Orleanian identity as a lived experience ("the city that lives in the imagination of the world," "good food, companionship, community") and the image seen from outside (music, exotic but "too fat, too rich" provincial food, stereotypes) is one of the main topics of season one. The interview with Creighton and the restaurant scene (Creighton at Jeanette's) put this in the focus, as well as the end scene of the third part of season one, when Mardi Gras Indians sing “Joc-a-mo-fee-nah-nay,” a ritual chant, as part of a funeral ceremony, while catastrophe tourists are coming on Katrina Tour.

Similarly, Davis refuses the stereotypical, commercial "New Orleans canon" of music, illustrated by ironic shots of the destroyed city while Louis Prima's Buona sera signorina is playing. Meanwhile, these spokesman-characters (two community activists, a writer and a DJ) are represented being involved in an ironic matter, which can be interpreted as a sort of self-irony. For instance, Davis considers himself culturally black, but after being provoked, then knocked down and thrown out of a bar by black "bros" (in S1E5), it is evident that he remained a stranger "white boy" for them. Similarly, Creighton is also an enthusiastic convert, whose eccentric emotions lead him to depression and suicide. Quite bitter conclusion if we take them as self-reflexive narrative constructions. In addition, as a narrative instance, an ironic and self-ironic "implied author" manifests itself in Davis MacAlary's Musical Heritage Tour (S3E1), pointing at the anachronistic, even virtual position of the tradition in a city where the sacred 
places fostering rock and roll and jazz are ruined, closed or turned to laundry. Identity and otherness from a New Orleanian perspective lead to bitter irony. Apropos of Jewish studies, women studies and African studies, Creighton says: "It's all about identity. Who am I? I am a black Jewish woman" (S1E2). His irony is directed against the whole university system with its infertile, purely theoretic cultural studies: "don't do nothing but contemplate, it is the cult of me."

Another source of irony is the anachronistic aspect of traditional, tribal community, represented by Mardi Gras Indians. Delmond Lambreaux, son of Big Chief Lambreaux is not involved in this subculture, but he plays as session musician with Dr. John (S1E3), who is an emblematic propagator of N.O. heritage. When his agent wants to make a N.O. brand of him in the fourth episode, he says: "I'm from New Orleans but I'm not playing New Orleans." When musicians talk about New Orleans in the third episode, Delmond criticizes the lack of respect: "New Orleans hypes the music but don't love musicians;" while others say: "there's no place to like musicians" because of the tradition. Finally, he takes part in the Mardi Gras Indians' march, and becomes a combatant for the living tradition of New Orleans (S2E1). This fact symbolizes that tradition goes on through music - not by pre-fabricated narratives.

Thus, music has manifold importance in Treme, appearing as the only way to represent the lived experience in this Afro-American creole Indian community, which is "all connected somehow" (S2E6). It is the lived experience's shapelessness and contingency what results in non-narrative scenes and reflexive statements such as Creighton's ("there is no closure in real life," S1E9) or that of Jeanette's response to David (S1E9): "There are so many beautiful moments here." - "There are just moments, but not a life." Transgressive elements of real life as cameo appearances and documentary traits have the same effect as juxtaposition and rhizomatic narrative.

Music, especially with lyrics, can illustrate, dub the plot, expressing characters' emotions or the "implied author's" opinion about the way things are going in this at once factual and fictional world. In a special case, the character who is listening also sings up, transgressing the borderline between facts and fiction. That is the case when Antoine sings a blues in the hospital in an ironic way (S1E4) or when Ollie \& The Nightingales is playing in the radio in Ladonna's bar and Antoine sings it to her.

More interesting is the case when music does not merely illustrate the story, but oppositely, music itself is illustrated by the rhizomatic narrative structure of life, that is, contingency and spontaneity. Thus, spontaneity of jamming 
(especially that of Mardi Gras Indians practising, e.g. S1E4) is at once a structural mise en abyme (and this self-reflexive character is very important in Treme) and a metonymy of a bottom-up organized ("rhizomatic") cultural community. Its life is rather spontaneous, just like jamming in music.

\section{Rhizome vs. Mimesis}

As mentioned before, though apparently spontaneity and rhizomatic organization characterize the narrative of Treme, there is an inconsistency with the mirror function, put down to a committed authorial intention. Multiplicity does not fit the binary Aristotelian logic, the one and only truth. One way to resolve this paradox is to redefine what a rhizomatic narrative is. Thus, some new narratological models might be worth mentioning, which derive from the traditional ones of Gerald Prince, Dorrit Cohn and others. For Dorrit Cohn, "narrative is a series of statements that deal with a causally related sequence of events that concern human (or human-like) beings" (Cohn 1999, 12). This is in accordance with Gerald Prince's definition, by which narrative is "the representation of at least two real or fictive events in a time sequence, neither of which presupposes or entails the other" (Prince 1982, 4). Sequentiality and causality are interconnected in this vision of linearity. On the contrary, Beatriz Penas Ibanez analyses narratives "in which narrativity and intertextuality interact in order to create a branching text whose virtual space is a multidimensional network of possible routes" (Ibanez 2008, 214). Similarly, the model of narrativizing (instead of narrative as rigid entity) stems from the multilinearity of kaleidoscope narratives discussed by Jukka Tyrkkö (Tyrkkö 2008). This kind of narrative is always the reader's - or in our case, the viewer's - work in progress. (In an ideal kaleidoscope narrative, the variety of possible alternative plots depends on hypertextual links or associations instead of linear causality.)

Though David Simon has an obvious affinity for these non-linear narratives, and New Orleans as the Dyonysiac city would be a perfect material in accordance with the intermedial capacity of music, it seems that the lack of "narratorial distance" (that is, the unsubtle presence of the implied author's vision in spite of the zero focalization) makes Treme a radicle-like fake rhizome that has no confidence in the viewer's judgement and hermeneutical capacity. However, to become dialogized in the Bakhtinian sense, Simon's documentarist fiction should have followed the poetics of John Dos Passos's Manhattan Transfer and the German New Objectivity (Neue Sachlichkeit), focusing on montage, on 
simultaneity and on reportage to break the illusion of reality, having the aim of making the audience think about certain social phenomena, not to tell them the truth about themselves. Without this consequent narrative a-linearity, the carnivalesque stays restricted and lacks the real subversive potential of the Socratic dialogues. Thus, Simon did not manage to produce "indeterminacy, a certain semantic openendedness, a living contact with unfinished, still-evolving contemporary reality (the openended present)" (Bakhtin 1981a, 7) while being attached to "historically concrete, living things" (Bakhtin, 1981b, 330). On the whole, Simon's social criticism resulted in a univocal mimetic representation of a par excellence Dyonysiac, dialogic, rhizomatic, hybrid topic: the lived experience of the Big Easy.

\section{References}

Bakhtin, Mikhail M. 1981a. Epic and Novel. In The Dialogic Imagination: Four Essays, ed. Michael Holquist, 3-40. Austin: University of Texas Press.

Bakhtin, Mikhail M. 1981b. Discourse in the Novel. In The Dialogic Imagination: Four Essays, ed. Michael Holquist, 269-422. Austin: University of Texas Press. Beiser, Vince. 2011. An Interview with David Simon. The Progressive March: 33-36.

http://progressive.org/david_simon_interview.html. Last accessed 19. 02. 2015. Cohen, Robin. 2007. Creolization and Cultural Globalization: The Soft Sounds of Fugitive Power. Globalizations vol. 4 no. 3:369-384. Irefer to the author's version: http://www2.warwick.ac.uk/fac/soc/sociology/rsw/current/cscs/working_ papers/creolization_and_cultural_globalization_the_soft_sounds_of_fugitive_ power.pdf. Last accessed 19. 02. 2015.

Cohn, Dorrit. 1999. The Distinction of Fiction. Baltimore: Johns Hopkins University Press.

Dällenbach, Lucien. 1977. Le Récit spéculaire. Essai sur la mise en abyme. Paris: Seuil.

Dawdy, Shannon Lee and Christopher N. Matthews. 2010. Colonial and Early Antebellum New Orleans. In Archeology of Louisiana, ed. Mark A. Rees, 273290. Baton Rouge: Louisiana State University Press.

Deleuze, Gilles and Felix Guattari. 1987. A Thousand Plateaus. Minneapolis, London: University of Minnesota Press.

Hannerz, Ulf. 1992. Cultural Complexity: Studies in the Social Organization of Meaning. New York: Columbia University Press. 
Ibanez, Beatriz Penas. 2008. A Pragma-Stylistic Contribution to the Study of Narrativity. In Theorizing Narrativity, eds. John Pier and José Angel Garcia Landa, 211-254. Berlin, New York: Walter de Gruyter.

Knight, Ryland Walker. 2011. A Cluster of Ideas on "Contagion.” Notebook. http:// mubi.com/notebook/posts/a-cluster-of-ideas-on-contagion. Last accessed 19. 02. 2015.

Nietzsche, Friedrich. 1926. The Birth of Tragedy or Hellenism and Pessimism. New York: Macmillan.

Nietzsche, Friedrich. 2013. The Twilight of the Idols or How to Philosophize with a Hammer. Transl. Daniel Fidel Ferrer. Open Source Books (Community Books). http://archive.org/details/ TwilightOfTheIdolsOrHowToPhilosophizeWithAHammer. Last accessed 19. 02. 2015.

Owen, Paul. 2011a. Treme: Season One, Episode One. TV\&Radio Blog. http://www.theguardian.com/tv-and-radio/tvandradioblog/2011/feb/18/ treme-season-one-episode-one. Last accessed 19. 02. 2015.

Owen, Paul. 2011b. Treme: Season One, Episode 3. TV\&Radio Blog. http://www. theguardian.com/tv-and-radio/tvandradioblog/2011/mar/04/treme-seasonone-episode-three. Last accessed 19. 02. 2015.

Owen, Paul. 2011c. Treme: Season One, Episode 10 - Season Finale. TV\&Radio Blog. http://www.theguardian.com/tv-and-radio/tvandradioblog/2011/apr/22/ treme-season-one-episode-10-season-finale. Last accessed 19. 02. 2015.

Prince, Gerald. 1982. Narratology: The Form and Functioning of Narrative. Amsterdam: Mouton.

Sepinwall, Alan. 2010. Interview: Treme Co-Creator David Simon Post-Mortems Season One. On Music, Anger and Katrina."What's Alan Watching” Blog. http://www.hitfix.com/blogs/whats-alan-watching/posts/interview-treme-cocreator-david-simon-post-mortems-season-one\#zyiAV5SfAo8xoSMo.99. Last accessed 19. 02. 2015.

Sermijn, Jasmina, Patrick Devlieger and Gerrit Loots. 2008. The Narrative Construction of the Self. Selfhood as a Rhizomatic Story. Qualitative Inquiry vol. 14 no. 4: 632-650. I refer to the author's version: http://soc.kuleuven.be/ web/files/11/69/QI314356_Rev11.pdf. Last accessed 19. 02. 2015.

Shaerf, David. 2010. Rhizomes and Non-Linear Pathways: New Approaches to Narrative in the Competitive Hobbyist Documentary. Doctoral Thesis, University of Exeter. 
Spitzer, Nick. 2011. Creolization as Cultural Continuity and Creativity in Postdiluvian New Orleans and Beyond. Southern Spaces. http://www. southernspaces.org/2011/creolization-cultural-continuity-and-creativitypostdiluvian-new-orleans-and-beyond\#sthash.df8JeBHe.dpuf. Last accessed 19. 02. 2015.

Tyrkkö, Jukka. 2008. Kaleidoscope Narratives and the Act of Reading. In Theorizing Narrativity, eds. John Pier and José Angel Garcia Landa, 277-306. Berlin, New York: Walter de Gruyter. 